ISSN 1660-3397

www.mdpi.com/journal/marinedrugs

Article

\title{
Four Eremophilane Sesquiterpenes from the Mangrove Endophytic Fungus Xylaria sp. BL321
}

Yongxiang Song ${ }^{1,2}$, Jiajian Wang ${ }^{1}$, Hongbo Huang ${ }^{1,2}$, Lin Ma ${ }^{1}$, Jun Wang ${ }^{3,4}$, Yucheng Gu ${ }^{5}$, Lan Liu ${ }^{1,3, *}$ and Yongcheng Lin ${ }^{1,3, *}$

1 School of Chemistry and Chemical Engineering, Sun Yat-Sen University, 135 Xingang West Road, Guangzhou 510275, China; E-Mails: songxiang0517@126.com (Y.S.); kakinvono@gmail.com (J.W.); huanghb@scsio.ac.cn (H.H.); cesmal@mail.sysu.edu.cn (L.M.)

2 CAS Key Laboratory of Marine Bio-resources Sustainable Utilization, Guangdong Key Laboratory of Marine Materia Medica, RNAM Center for Marine Microbiology, South China Sea Institute of Oceanology, Chinese Academy of Sciences, 164 West Xingang Rd., Guangzhou 510301, China

3 Guangdong Province Key Laboratory of Functional Molecules in Oceanic Microorganism (Sun Yat-Sen University), Bureau of Education of Guangdong, Guangzhou, 510275, China; E-Mail:wjun@mail.sysu.edu.cn

4 School of Pharmaceutical Sciences, Sun Yat-Sen University, Guangzhou 510080, China

5 Syngenta Jealott's Hill International Research Centre, Bracknell, Berkshire, RG42 6EY, UK; E-Mail: yucheng.gu@syngenta.com

* Authors to whom correspondence should be addressed; E-Mails: cesllan@mail.sysu.edu.cn (L.L.); ceslyc@mail.sysu.edu.cn (Y.L.); Tel./Fax:+86-20-8403-9623.

Received: 2 December 2011; in revised form: 17 January 2012 / Accepted: 17 January 2012 / Published: 6 February 2012

Abstract: Three new eremophilane sesquiterpenes (1-3) were isolated from the mangrove endophytic fungus Xylaria sp. BL321 together with 07H239-A (4), a known analogue of the new compounds. The structures of these compounds were elucidated by analysis of their MS, 1D and 2D NMR spectroscopic data. Compound 4 showed activation activity on $\alpha$-glucosidase at $0.15 \mu \mathrm{M}(146 \%)$, and then, 4 gradually produced inhibitory activity on $\alpha$-glucosidase with increasing concentration, and the $\mathrm{IC}_{50}$ value is $6.54 \mu \mathrm{M}$.

Keywords: marine fungus; Xylaria sp.; mangrove; sesquiterpenes; $\alpha$-glucosidase 


\section{Introduction}

Many structurally novel and biologically active metabolites have been isolated and characterized from the fungal genus Xylaria, including cytochalasins [1-3], phytotoxins [2], xyloketals [4-7], cyclopeptides [8-10], lactones [11,12], xanthones [13,14], sesquiterpenes [15,16], and aromatic derivatives [17,18]. Our previous studies on the mangrove endophytic fungus Xylaria sp. 2508 had led to the isolation of a series of the above mentioned compounds [5-10,17,18]. These findings on fungus Xylaria sp. 2508 encouraged chemical research resulting in the isolation of two new lactones from a endophytic fungus Xylaria sp. BL321 [19]. The current study presents additional chemical investigation performed on Xylaria sp. BL321 that led to the discovery of three new eremophilane sesquiterpenes (1-3) and a known analogue 07H239-A (4) [15] isolated by extensive silica gel column chromatography and semipreparative HPLC.

Herein, we report the isolation, structure elucidation and enzyme-based biological assays against $\alpha$-glucosidase of the four eremophilane sesquiterpenes.

\section{Results and Discussion}

Compound 1 was obtained as a white solid. The HREIMS results established the molecular formular $\mathrm{C}_{26} \mathrm{H}_{34} \mathrm{O}_{6}\left(\mathrm{~m} / z 442.2345[\mathrm{M}]^{+}\right.$, calcd. 442.2350), and suggested ten degrees of unsaturation in the structure of this compound. Its IR spectrum indicated the presence of a hydroxyl group at $3300 \sim 2700 \mathrm{~cm}^{-1}$ and carbonyl, together with conjugated carbonyl absorptions at 1728, 1705, 1682 and $1648 \mathrm{~cm}^{-1}$. The UV absorption band at $261 \mathrm{~nm}$ showed the present of a conjugated dienoate system. The existence of a ketone carbonyl $\left(\delta_{\mathrm{C}} 197.1, \mathrm{C}-8\right)$, a formyl group $\left(\delta_{\mathrm{H}} 9.56, \delta_{\mathrm{C}} 193.3, \mathrm{C}-12\right)$, a carboxyl group $\left(\delta_{\mathrm{C}} 177.6, \mathrm{C}-14\right)$, and an ester carbonyl $\left(\delta_{\mathrm{C}} 165.9, \mathrm{C}-1^{\prime}\right)$ were confirmed by the ${ }^{1} \mathrm{H},{ }^{13} \mathrm{C}$ and HMQC NMR data (Table 1). The NMR data also supported the existence of three methyls, seven methylenes including a terminal olefinic carbon (C-13), five unsaturated methines, four aliphatic methines, and three quaternary carbons. Analysis of the COSY spectrum disclosed three spin systems of H-1-H-4, H-6-H-7, and H-2'-H-10' and H-8'-H-11', which led to the establishment of the structure fragments $\mathrm{C}-1-\mathrm{C}-4, \mathrm{C}-6-\mathrm{C}-7$, and the long side chain incorporated a 1,3-diene, respectively. The HMBC correlations of H-4/C-5 and H-6/C-5 suggested that fragments C-1-C-4 and C-6-C-7 were connected through a quaternary carbon $(\mathrm{C}-5)$. An isolated methyl $\left(\delta_{\mathrm{H}} 1.54, \delta_{\mathrm{C}} 19.8, \mathrm{C}-15\right)$ was linked to $\mathrm{C}-5$ supported by the HMBC correlations of $\mathrm{H}_{3}-15 / \mathrm{C}-4, \mathrm{C}-5, \mathrm{C}-6$. The HMBC cross peaks of $\mathrm{H}-13 / \mathrm{C}-11$, and of $\mathrm{H}-12 / \mathrm{C}-11, \mathrm{C}-13$ indicated that the formyl group (C-12) was attached to a terminal olefin (C-11-C-13) to build the acrylaldehyde moiety. Further HMBC correlations of H-12/C-7 and $\mathrm{H}-13 / \mathrm{C}-7$ located the unsaturated aldehyde at $\mathrm{C}-7$. The carbonyl (C-8) was conjugated with an olefinic bond (C-9-C-10) to form an $\alpha, \beta$-unsaturated ketone, which was proved by the HMBC correlation of $\mathrm{H}-9 / \mathrm{C}-8$ and $\mathrm{H}-9 / \mathrm{C}-10$. These HMBC correlations from $\mathrm{H}-9$ to $\mathrm{C}-1, \mathrm{C}-7, \mathrm{C}-5$, from $\mathrm{H}_{3}-15$ to $\mathrm{C}-10$, and from $\mathrm{H}-6$ to $\mathrm{C}-8, \mathrm{C}-10$ established the two six-membered rings backbone. This structure elucidation was in agreement with the remaining two degrees of unsaturation. The HMBC correlation between the proton of the oxygen-bearing methine (C-1) and the carbonyl (C-1') implied the presence of an ester bond at $\mathrm{C}-1$. The ${ }^{13} \mathrm{C}$ NMR chemical shift $\left(\delta_{\mathrm{C}} 165.9\right)$ of carbonyl carbon indicated it was connected with the 1,3-diene to form a conjugated system as evident by the HMBC correlation of $\mathrm{H}-3^{\prime} / \mathrm{C}-1^{\prime}$. As 
determined from the HMBC correlation of $\mathrm{H}-4 / \mathrm{C}-14$, the carboxyl group was linked to $\mathrm{C}-4$. Thus, the planar structure of compound 1 was established.

Table 1. ${ }^{1} \mathrm{H}$ and ${ }^{13} \mathrm{C}$ NMR data of compounds $\mathbf{1}-\mathbf{3}, J$ in $\mathrm{Hz}$.

\begin{tabular}{|c|c|c|c|c|c|c|}
\hline & $1^{a}$ & & & $2^{b}$ & & $3^{b}$ \\
\hline Position & $\boldsymbol{\delta}_{\mathrm{C}, \text { mult. }}$ & $\delta_{H}(J$ in Hz $)$ & $\boldsymbol{\delta}_{\mathrm{C}}$, mult. & $\delta_{\mathrm{H}}(J$ in $\mathrm{Hz})$ & $\boldsymbol{\delta}_{\mathrm{C}, \text { mult. }}$ & $\delta_{H}(J$ in Hz $)$ \\
\hline 1 & $72.7, \mathrm{CH}$ & $5.54,(\mathrm{t}, 3.0)$ & $72.7, \mathrm{CH}$ & $5.51,(\mathrm{t}, 3.0)$ & $73.0, \mathrm{CH}$ & $5.53,(\mathrm{bs})$ \\
\hline \multirow[t]{2}{*}{2} & $30.0, \mathrm{CH}_{2}$ & $2.17,(\mathrm{~m})$ & $29.9, \mathrm{CH}$ & $2.16,(\mathrm{~m})$ & 29.9, $\mathrm{CH}_{2}$ & $2.19,(\mathrm{~m})$ \\
\hline & & $1.75,(\mathrm{~m})$ & & $1.71,(\mathrm{~m})$ & & $1.75,(\mathrm{~m})$ \\
\hline \multirow[t]{2}{*}{3} & $20.2, \mathrm{CH}_{2}$ & $2.36,(\mathrm{~m})$ & $20.8, \mathrm{CH}_{2}$ & $2.31,(\mathrm{~m})$ & $20.3, \mathrm{CH}_{2}$ & $2.32,(\mathrm{~m})$ \\
\hline & & $1.87,(\mathrm{~m})$ & & $1.81,(\mathrm{~m})$ & & $1.75,(\mathrm{~m})$ \\
\hline 4 & $53.5, \mathrm{CH}$ & $2.47,(\mathrm{dd}, 13.2,3.1)$ & $53.3, \mathrm{CH}$ & $2.45,(\mathrm{~d}, 12.5)$ & $53.6, \mathrm{CH}$ & $2.47,(\mathrm{~m})$ \\
\hline 5 & $38.6, \mathrm{C}$ & & $38.6, \mathrm{C}$ & & $38.5, \mathrm{C}$ & \\
\hline \multirow[t]{2}{*}{6} & $43.4, \mathrm{CH}_{2}$ & $2.30,(\mathrm{~m})$ & $43.5, \mathrm{CH}_{2}$ & $2.29,(\mathrm{~m})$ & $43.4, \mathrm{CH}_{2}$ & $2.31,(\mathrm{~m})$ \\
\hline & & $2.14,(\mathrm{~m})$ & & $2.13,(\mathrm{~m})$ & & $2.16,(\mathrm{~m})$ \\
\hline 7 & $43.3, \mathrm{CH}$ & $3.75,(\mathrm{dd}, 14.7,4.6)$ & $43.4, \mathrm{CH}$ & $3.71,(\mathrm{dd}, 14.2,3.7)$ & $43.4, \mathrm{CH}$ & $3.74,(\mathrm{~d}, 13.0)$ \\
\hline 8 & 197.1, C & & 197.0, C & & 197.0, C & \\
\hline 9 & $129.8, \mathrm{CH}$ & $6.12,(\mathrm{~s})$ & $129.8, \mathrm{CH}$ & $6.09,(\mathrm{~s})$ & $129.8, \mathrm{CH}$ & $6.10,(\mathrm{~s})$ \\
\hline 10 & 159.1, C & & $159.2, \mathrm{C}$ & & $159.3, \mathrm{C}$ & \\
\hline 11 & $147.9, \mathrm{C}$ & & 148.0, C & & 147.9, C & \\
\hline 12 & 193.3, CH & $9.56,(\mathrm{~s})$ & 193.3, CH & $9.52,(\mathrm{~s})$ & 193.3, CH & $9.54,(\mathrm{~s})$ \\
\hline \multirow[t]{2}{*}{13} & 136.6, $\mathrm{CH}_{2}$ & $6.37,(\mathrm{~s})$ & 136.6, $\mathrm{CH}_{2}$ & $6.33,(\mathrm{~s})$ & 136.6, $\mathrm{CH}_{2}$ & $6.36,(\mathrm{~s})$ \\
\hline & & $6.26,(\mathrm{~s})$ & & $6.22,(\mathrm{~s})$ & & $6.24,(\mathrm{~s})$ \\
\hline 14 & 177.6, C & & not observed & & not observed & \\
\hline 15 & $19.8, \mathrm{CH}_{3}$ & $1.54,(\mathrm{~s})$ & $19.9, \mathrm{CH}_{3}$ & $1.24,(\mathrm{~s})$ & $19.8, \mathrm{CH}_{3}$ & $1.56,(\mathrm{~s})$ \\
\hline $1^{\prime}$ & $165.9, \mathrm{C}$ & & $166.3, \mathrm{C}$ & & $167.3, \mathrm{C}$ & \\
\hline $2^{\prime}$ & $118.6, \mathrm{CH}$ & $5.77,(\mathrm{~d}, 15.2)$ & $114.9, \mathrm{CH}$ & $5.72,(d, 15.5)$ & 124.7, C & \\
\hline $3^{\prime}$ & $146.3, \mathrm{CH}$ & $7.28,(\mathrm{ddd}, 15.2,6.4,3.6)$ & $151.0, \mathrm{CH}$ & $7.29,(\mathrm{~d}, 15.5)$ & $140.1, \mathrm{CH}$ & $7.15,(d, 11.3)$ \\
\hline $4^{\prime}$ & $128.2, \mathrm{CH}$ & $6.20,(\mathrm{~m})$ & 132.7, C & & $124.2, \mathrm{CH}$ & $6.30,(\mathrm{dd}, 15.0,11.3)$ \\
\hline $5^{\prime}$ & $146.4, \mathrm{CH}$ & $6.18,(\mathrm{~m})$ & 144.0, CH & $5.91,(\mathrm{t}, 7.4)$ & $150.3, \mathrm{CH}$ & $5.93,(\mathrm{dd}, 15.0,8.5)$ \\
\hline $6^{\prime}$ & $30.9, \mathrm{CH}_{2}$ & $2.19,(\mathrm{~m})$ & $26.8, \mathrm{CH}_{2}$ & $2.20,(\mathrm{~m})$ & $35.6, \mathrm{CH}$ & $2.39,(\mathrm{~m})$ \\
\hline \multirow[t]{2}{*}{$7^{\prime}$} & $35.6, \mathrm{CH}_{2}$ & 1.47, (m) & $30.0, \mathrm{CH}_{2}$ & $1.42,(\mathrm{~m})$ & $32.2, \mathrm{CH}$ & $1.31,(\mathrm{~m})$ \\
\hline & & $1.27,(\mathrm{~m})$ & & $1.22,(\mathrm{~m})$ & $44.2, \mathrm{CH}_{2}$ & $1.35,(\mathrm{~m})$ \\
\hline $8^{\prime}$ & $34.2, \mathrm{CH}_{2}$ & $1.36,(\mathrm{~m})$ & $34.3, \mathrm{CH}$ & $1.33,(\mathrm{~m})$ & & $1.13,(\mathrm{~m})$ \\
\hline \multirow[t]{2}{*}{$9^{\prime}$} & $29.5, \mathrm{CH}_{2}$ & $1.39,(\mathrm{~m})$ & $35.9, \mathrm{CH}_{2}$ & $1.15,(\mathrm{~m})$ & $11.5, \mathrm{CH}_{3}$ & $0.82,(\mathrm{t}, 6.2)$ \\
\hline & & $1.17,(\mathrm{~m})$ & & & & \\
\hline $10^{\prime}$ & $11.5, \mathrm{CH}_{3}$ & $0.87,(\mathrm{t}, 7.2)$ & $19.2, \mathrm{CH}_{3}$ & $0.87,(\mathrm{t}, 6.2)$ & $12.9, \mathrm{CH}_{3}$ & $1.94,(\mathrm{~s})$ \\
\hline $11^{\prime}$ & $19.2, \mathrm{CH}_{3}$ & $0.89,(\mathrm{~d}, 6.4)$ & $12.3, \mathrm{CH}_{3}$ & $1.76,(\mathrm{~s})$ & $21.4, \mathrm{CH}_{3}$ & $1.04,(\mathrm{~d}, 6.7)$ \\
\hline $12^{\prime}$ & & & $11.5, \mathrm{CH}_{3}$ & $0.81,(\mathrm{~d}, 6.3)$ & $19.2, \mathrm{CH}_{3}$ & $0.81,(3 \mathrm{H}, \mathrm{d}, 7.3)$ \\
\hline
\end{tabular}

${ }^{\text {a }}$ Measured in $\mathrm{CDCl}_{3}$ at $400 \mathrm{MHz}\left({ }^{1} \mathrm{H}\right)$ and $100 \mathrm{MHz}\left({ }^{13} \mathrm{C}\right) ;{ }^{\mathrm{b}}$ Measured in $\mathrm{CDCl}_{3}$ at $500 \mathrm{MHz}\left({ }^{1} \mathrm{H}\right)$ and $125 \mathrm{MHz}\left({ }^{13} \mathrm{C}\right)$.

The relative configuration of 1 was determined by ${ }^{3} J_{\mathrm{H}-\mathrm{H}}$ values in ${ }^{1} \mathrm{H}$ NMR spectrum and NOESY experiment (Figure 1). The small coupling constant $\left({ }^{3} J_{\mathrm{H}-\mathrm{H}}=2.6 \mathrm{~Hz}\right)$ of $\mathrm{H}-1 / \mathrm{H}-2$ indicated that the H-1 was equatorially oriented, which was supported by the correlation of $\mathrm{H}-1 / \mathrm{H}-9$ in NOESY. The large coupling constants of H-4/H-3 and H-7/H-6 ( ${ }^{3} J_{\mathrm{H}-\mathrm{H}}=13.2,14.7 \mathrm{~Hz}$, respectively) suggested $\mathrm{H}-4$ and $\mathrm{H}-7$ have axial orientation. The NOESY correlation between $\mathrm{H}-7$ and $\mathrm{H}_{3}-15$ located $\mathrm{CH}_{3}-15$ and $\mathrm{H}-7$ at 
the same side of the molecular surface, which led to the trans configuration of $\mathrm{H}_{3}-15 / \mathrm{H}-4$. The strongly coupled protons at the double bond C-2'-C-3' $\left({ }^{3} J_{\mathrm{H}-\mathrm{H}}=15.2 \mathrm{~Hz}\right)$ defined $E$-configuration to this olefinic bond. Though the coupling constant of $\mathrm{H}^{-} \mathbf{4}^{\prime} / \mathrm{H}-5^{\prime}$ was not able to be determined due to the overlapped signals, the $Z$-configuration was assigned to the double bond $\mathrm{C}-4^{\prime}-\mathrm{C}-5^{\prime}$ on the basis of the NOE between H-3' and H-6'. Therefore, compound $\mathbf{1}$ was identified as a new eremophilane sesquiterpene as shown in Figure 2.

Figure 1. COSY, Key HMBC, and NOESY correlations of compound $\mathbf{1 .}$
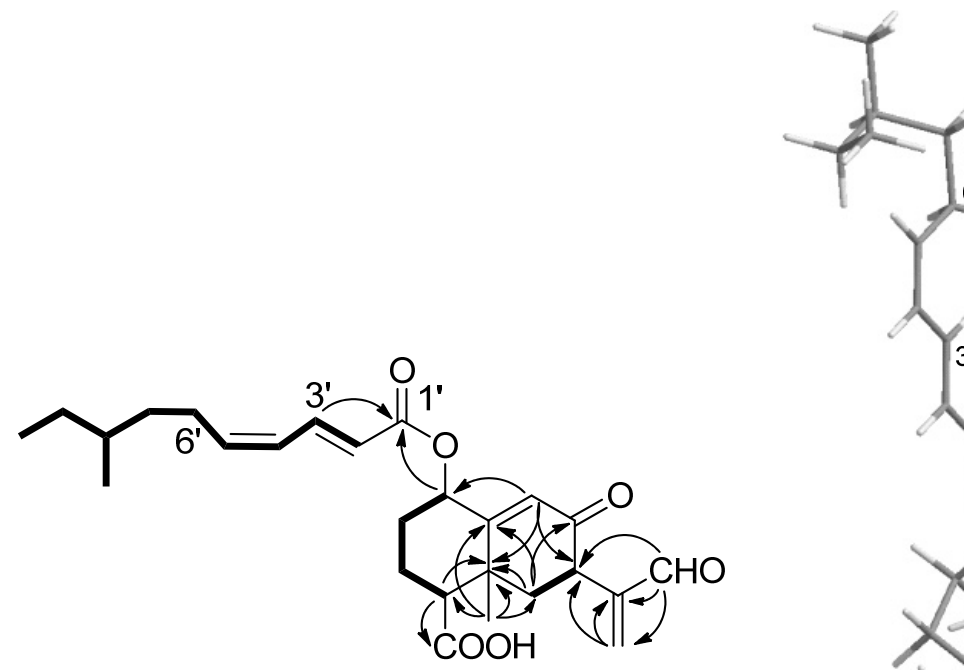

- $1 \mathrm{H}^{-1} \mathrm{HCOSY} \curvearrowright \mathrm{HMBC} \curvearrowleft \mathrm{NOESY}$

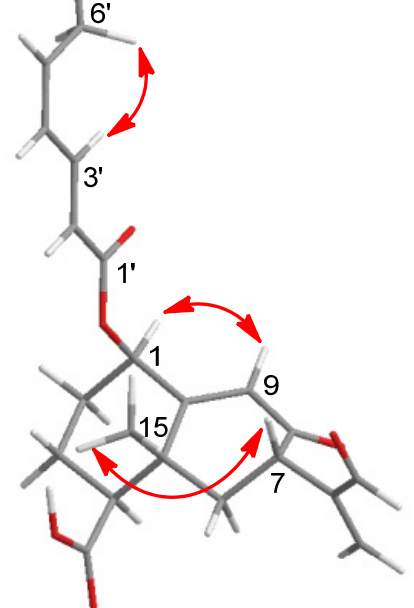

Figure 2. Structure of compounds 1-4 isolated from fungus Xylaria sp. BL321.

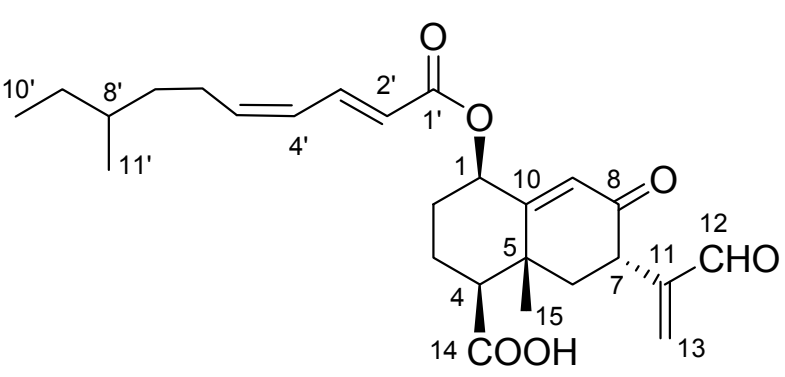

1

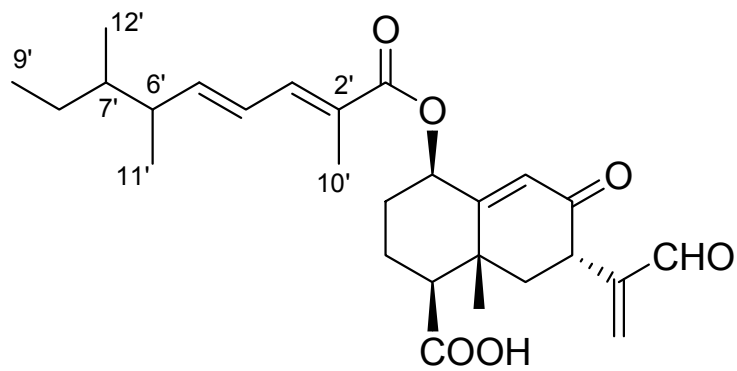

3

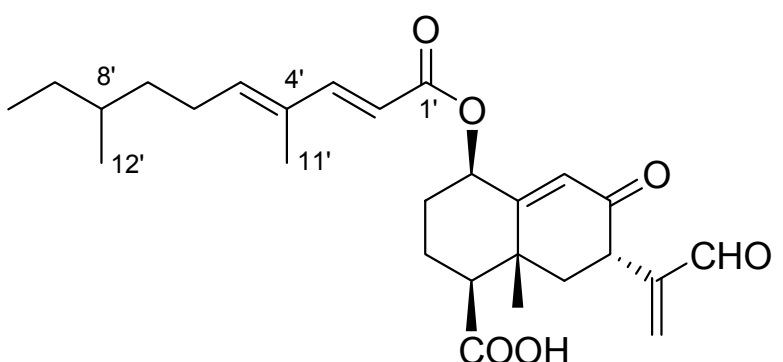

2<smiles>C=C(C=O)[C@H]1C[C@@]2(C)C(=CC1=O)[C@@H](OC(=O)/C=C/C=C/C(C)CC(C)CC)CC[C@H]2C(=O)O</smiles> 
Compound 2 was obtained as a white solid. Its molecular formula $\mathrm{C}_{27} \mathrm{H}_{36} \mathrm{O}_{6}$ was established from the peak at $m / z 455.2446\left([\mathrm{M}-\mathrm{H}]^{-}\right.$, calcd. 455.2434) revealed by HRESIMS, which is 14 mass unit higher than 1. The ${ }^{1} \mathrm{H}$ and ${ }^{13} \mathrm{C}$ NMR spectroscopic data of $\mathbf{2}$ disclosed those structural features similar to those found in 1 (Table 1), except the unsaturated proton $\left(\delta_{\mathrm{H}} 6.20, \mathrm{H}-4^{\prime}\right)$ signal in 1 was missing, and an unsaturated quaternary carbon signal $\left(\delta_{\mathrm{C}} 132.7, \mathrm{C}-4{ }^{\prime}\right)$ and an additional isolated methyl signal $\left(\delta_{\mathrm{H}} 1.76, \mathrm{~s} ; \delta_{\mathrm{C}} 12.3, \mathrm{C}-11^{\prime}\right)$ were observed. Its ${ }^{13} \mathrm{C}$ NMR chemical shift value of C-3' shifted downfield from $\delta_{\mathrm{C}} 146.3$ in $\mathbf{1}$ to $\delta_{\mathrm{C}} 150.0$ in $\mathbf{2}$. Comprehensive comparison of the NMR spectra of $\mathbf{2}$ with that of $\mathbf{1}$ revealed that the olefinic proton (H-4') at the side chain of 1 was replaced by a methyl group (C-11') in 2. This was supported by the COSY correlations of $\mathrm{H}-5^{\prime}-\mathrm{H}-10^{\prime}, \mathrm{H}-12^{\prime} / \mathrm{H}-8^{\prime}$ and $\mathrm{H}-2^{\prime} / \mathrm{H}-3^{\prime}$, and the HMBC correlations from H-11' to C-3', C-4', C-5'. (Figure 3) The configuration of the two double bonds were assigned to be $E$ configuration due to the large coupling constant $\left({ }^{3} J_{\mathrm{H}-\mathrm{H}}=15.5 \mathrm{~Hz}\right)$ of $\mathrm{H}-2^{\prime} / \mathrm{H}-3^{\prime}$, as well as the NOE correlations of $\mathrm{H}-6^{\prime} / \mathrm{H}-11^{\prime}$ and $\mathrm{H}-3^{\prime} / \mathrm{H}-5^{\prime}$. The relative configuration of C-1, C-4, C-5 and C-7 were assigned as the same as those in $\mathbf{1}$ on the basis of the similar coupling constants. Thus, the structure of $\mathbf{2}$ was established as shown in Figure 2.

Compound 3 shares the same molecular formula of $\mathrm{C}_{27} \mathrm{H}_{36} \mathrm{O}_{6}$ with $\mathbf{2}$, as determined by the HRESIMS results. The ${ }^{1} \mathrm{H}$ and ${ }^{13} \mathrm{C}$ NMR data showed the presence of five methyl signals, indicating that 3 has two more methyl groups than 1. Furthermore, the unsaturated methine $\left(\mathrm{CH}-2^{\prime}\right)$ and the methylene $\left(\mathrm{CH}_{2}-6^{\prime}\right)$ signals in $\mathbf{1}$ were absent, while an additional unsaturated quaternary carbon signal at $\delta_{\mathrm{C}} 124.7\left(\mathrm{C}-2^{\prime}\right)$ and an additional methine at $\delta_{\mathrm{H}} 2.39, \delta_{\mathrm{C}} 35.6\left(\mathrm{CH}-6^{\prime}\right)$ were observed. Comparing the ${ }^{1} \mathrm{H}$ and ${ }^{13} \mathrm{C}$ NMR spectroscopic data of $\mathbf{3}$ with those of $\mathbf{1}$ and $\mathbf{2}$ revealed that $\mathbf{3}$ possess an identical double ring backbone to those found in $\mathbf{1}$ and $\mathbf{2}$, but with a different side chain at $\mathrm{C}-1$. The structure of this side chain was deduced from COSY and HMBC spectra. In the HMBC spectrum, the correlations from $\mathrm{H}_{3}-10^{\prime}$ to $\mathrm{C}-1$ ', $\mathrm{C}-2$ ', $\mathrm{C}-3$ ' linked the methyl group (Me-10') to quaternary $\mathrm{C}-2$ '. The COSY experiment gave a spin system of H-3'-H-9', H-6'-H-11', H-7'-H-12', establishing the remaining structural fragment of the side chain, as shown in Figure 3. The configurations of the two olefins on the side chain were determined to be $E$ in the same fashion as that in 2, based on ${ }^{3} J_{\mathrm{H}-4^{\prime} / \mathrm{H}-5^{\prime}}=15.5 \mathrm{~Hz}$ and the NOE of $\mathrm{H}-10^{\prime} / \mathrm{H}-4$ '.

Figure 3. Key COSY, HMBC, and NOESY correlations of the side chain in compounds 2-3.

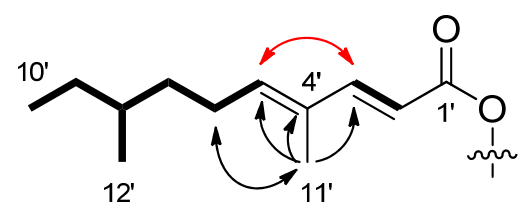

2

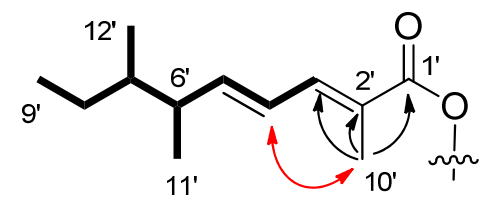

3

- ${ }^{1} \mathrm{H}-{ }^{1} \mathrm{HCOSY} \curvearrowright \mathrm{HMBC} \curvearrowleft \mathrm{NOESY}$

Compound 4 was isolated as the main product, which structure was determined to be the known compound $07 \mathrm{H} 239-\mathrm{A}$ by comparing the $1 \mathrm{D}$ and $2 \mathrm{D}$ data with the reported data in the literature [15].

The literature suggests that eremophilane sesquiterpenes with an ester side chain possess various biological activities. Compound $\mathbf{4}$ and its derivatives [20] showed cytotoxicity against cancer cell lines, while eremoxylarins A and B displayed antibacterial activity against Staphylococcus aureus and 
Pseudomonas aeruginosa [21], and Sch 420789 had phospholipase D inhibitory activity [22]. Unfortunately, the new eremophilane sesquiterpenes (1-3) did not show cytotoxic activity against the cell lines of MDA-MB-435, A549, Hep3B, PC-3 in our study, though their structures are highly related to that of $\mathbf{4}$. Compounds 1 and 4 were further evaluated for their effects on $\alpha$-glucosidase using an enzyme-based bioassay. Compound $\mathbf{1}$ had no detectable effect on $\alpha$-glucosidase. Compounds $\mathbf{4}$ showed the best activation effect on $\alpha$-glucosidase at the concentration of $0.15 \mu \mathrm{M}$, which enhanced the enzyme activity to a level of $146 \%$. However, compound 4 showed gradually higher inhibitory activity toward $\alpha$-glucosidase with increasing concentration, and an $\mathrm{IC}_{50}$ value of $6.54 \mu \mathrm{M}$. Compound $\mathbf{2}$ and $\mathbf{3}$ were not tested due to the limited amounts obtained.

\section{Experimental Section}

\subsection{General Experimental Procedures}

Melting points were determined on SFW-X-4 apparatus. Optical rotations measurements were carried out on a Polaptronic HNQW5 (Schmidt-Haensch) spectrometer. UV spectra were determined on a UV-2501 PC (Shzmadzu) spectrometer. IR spectra were measured on a 5DX-FTIR (Nicolet) spectrometer. ${ }^{1} \mathrm{H}$ NMR and ${ }^{13} \mathrm{C}$ NMR data were acquired on a Bruker AVANCE 400 spectrometer at $400 \mathrm{MHz}$ for ${ }^{1} \mathrm{H}$ nucleus and $100 \mathrm{MHz}$ for ${ }^{13} \mathrm{C}$ nucleus, and a Varian INOVA500NB spectrometer at $500 \mathrm{MHz}$ for ${ }^{1} \mathrm{H}$ nucleus and $125 \mathrm{MHz}$ for ${ }^{13} \mathrm{C}$ nucleus. TMS was used as an internal standard and chemical shifts $(\delta)$ were expressed in ppm. ESIMS, HRESIMS, EIMS and HREIMS were operated on LCQ-DECA-XP (Thermo), LCMS-IT-TOF (Shimadzu), DSQ (Thermo) and Mat95XP (Thermo) mass spectrometers, respectively. Column chromatography (CC) was carried out on silica gel (200-300 mesh, Qingdao Marine Chemical Inc.). HPLC was performed on a 515 pump with a UV 2487 detector (Waters) using an Ultimate XB-C18 column $(250 \times 10 \mathrm{~mm}, 5 \mu$; Welch $)$.

\subsection{Fermentation}

The small agar slice bearing mycelia, which were stocked and incubated at $25{ }^{\circ} \mathrm{C}$ on PDA (Potato Dextrose Agar) medium, was placed in GYT medium ( $1 \%$ glucose, $0.1 \%$ yeast extract, $0.2 \%$ peptone, $0.2 \%$ crude sea salt) in $500 \mathrm{~mL}$ Erlenmeyer flasks containing $250 \mathrm{~mL}$ GYT and incubated at $28{ }^{\circ} \mathrm{C}$, $120 \mathrm{rpm}$ for 6 days as seed culture. A $150 \mathrm{~L}$ large scale fermentation was performed using multiple $1000 \mathrm{~mL}$ Erlenmeyer flasks, each containing $500 \mathrm{~mL}$ GYT. Each flask was inoculated with $1 \mathrm{~mL}$ seed culture and incubated at $28{ }^{\circ} \mathrm{C}$ for 30 days under static conditions.

\subsection{Extraction and Isolation}

The smashed dry mycelia of the fungus were extracted using EtOAc (EA), and then the extract solution was concentrated to dryness. The EA extract was subjected to silica gel CC eluting with petroleum ether (PE)/EA mixtures of increasing polarity. The filtered fraction ( $c a .500 \mathrm{mg}$ ) eluted by PE/EA (65/35) was further isolated by using extensively semi-preparative RP HPLC eluted with $\mathrm{MeOH} / \mathrm{H}_{2} \mathrm{O} /$ acetic acid $(85 / 15 / 0.1)$ at a flow rate of $1.0 \mathrm{~mL} / \mathrm{min}$, detected under UV $254 \mathrm{~nm}$ and afford compounds 1 (41 mg, $\left.t_{R}=32.16\right), 2\left(5 \mathrm{mg}, t_{R}=45.88\right), 3\left(3 \mathrm{mg}, \mathrm{t}_{\mathrm{R}}=57.15\right), 4(340 \mathrm{mg}$, $\left.\mathrm{t}_{\mathrm{R}}=38.31\right)$, respectively. 
Compound 1: $\mathrm{mp} 159 \sim 161{ }^{\circ} \mathrm{C}$; $[\alpha]_{\mathrm{D}}^{25}-19$ (c 0.145, MeOH); UV (MeOH) $\lambda_{\max }(\log \varepsilon) 261(4.58) \mathrm{nm}$; IR $(\mathrm{KBr}) v_{\max } 3453,1728,1705,1682$ and $1648 \mathrm{~cm}^{-1} ;{ }^{1} \mathrm{H} \mathrm{NMR}\left(\mathrm{CDCl}_{3}, 400 \mathrm{MHz}\right),{ }^{13} \mathrm{C} \mathrm{NMR}\left(\mathrm{CDCl}_{3}\right.$, $100 \mathrm{MHz}$ ), see Table 1; EIMS m/z (rel. int.) $442[\mathrm{M}]^{+}$(0.5), 278 (4), 260 (24), 165 (100), 81 (34). HREIMS $m / z 442.2345[\mathrm{M}]^{+}$(calcd. for $\mathrm{C}_{26} \mathrm{H}_{34} \mathrm{O}_{6}, 442.2350$ ).

Compound 2: mp 141 143 ${ }^{\circ} \mathrm{C}$; $[\alpha]^{25}{ }_{\mathrm{D}}-14$ (c 0.047, MeOH); UV (MeOH) $\lambda_{\max }(\log \varepsilon) 262$ (4.86) $\mathrm{nm}$; IR (KBr) $v_{\max } 3366,1726,1683,1647$ and $1621 \mathrm{~cm}^{-1} ;{ }^{1} \mathrm{H} \mathrm{NMR}\left(\mathrm{CDCl}_{3}, 500 \mathrm{MHz}\right),{ }^{13} \mathrm{C} \mathrm{NMR}$ $\left(\mathrm{CDCl}_{3}, 125 \mathrm{MHz}\right.$ ), see Table 1; EIMS m/z (rel. int.): 278 (3), 260 (48), 91 (100). HRESIMS $m / z 455.2446[\mathrm{M}-\mathrm{H}]^{-}$(calcd. for $\mathrm{C}_{27} \mathrm{H}_{36} \mathrm{O}_{6}, 455.2434$ ).

Compound 3: $[\alpha]^{25}-47\left(c\right.$ 0.052, MeOH); UV (MeOH) $\lambda_{\max }(\log \varepsilon) 269$ (4.06) nm; IR (KBr) $v_{\max }$ 3394, 1732, 1704, 1680 and $1651 \mathrm{~cm}^{-1}$; ${ }^{1} \mathrm{H} \mathrm{NMR}\left(\mathrm{CDCl}_{3}, 500 \mathrm{MHz}\right),{ }^{13} \mathrm{C} \mathrm{NMR}\left(\mathrm{CDCl}_{3}, 125 \mathrm{MHz}\right)$, see Table 1; EIMS, m/z (rel. int.): 278 (1), 260 (98), 111 (100), 69 (52). HRESIMS m/z 455.2441 $[\mathrm{M}-\mathrm{H}]^{-} \mathrm{C}_{27} \mathrm{H}_{36} \mathrm{O}_{6}$ (calcd. for 455.2434).

\subsection{Biological Assays}

The enzyme-based assay against $\alpha$-glucosidase was operated using a modified method based on those previously reported [23,24]. Briefly, $\alpha$-glucosidase activity was assayed with $1 \mathrm{~mL}$ reaction volume in $0.01 \mathrm{M}$ phosphate buffer solution (PBS) at $\mathrm{pH} 7.0$, while $p$-nitrophenyl- $\alpha$-D-glucopyranoside (PNPG) was used as substrate. $10 \mu \mathrm{L}$ of enzyme solution (5 U/mL in PBS), $950 \mu \mathrm{L}$ PBS and $20 \mu \mathrm{L}$ the tested compound (solution in DMSO) were mixed and incubated at $37{ }^{\circ} \mathrm{C}$ for $20 \mathrm{~min}$, and then the substrate PNPG $20 \mu \mathrm{L}(3 \mathrm{mg} / \mathrm{mL})$ was added to initiate the enzyme reaction. The absorbance was immediately determined at $400 \mathrm{~nm}$ with spectrophotometer.

\section{Conclusions}

This investigation has led to the isolation of four eremophilane sesquiterpenes including the known compound 07H239-A (4), which enriched this family of compounds. Compounds 1-3 were found to be inactive to the test cell lines, which supported that their side chain may play an important role in the cytotoxic activity [20]. The activity of compound $\mathbf{4}$ against $\alpha$-glucosidase was found for the first time.

\section{Acknowledgments}

This work was supported by The National Natural Science Foundation of China (20972197), The Science \& Technology Plan Project of Guangdong Province of China (2010B030600004), China's Marine Commonweal Research Project 201005022-2 and The Fundamental Research Funds for the Central Universities (101gpy11). We would also like to thank Syngenta Ltd. for awarding a PhD studentship to Yongxiang Song and Henry Gu in the Faculty of Medicine, Imperial College London, UK for proof-reading the manuscript. 


\section{References}

1. Aldridge, D.C.; Turner, W.B. Stryctures of cytochalasins C and D. J. Chem. Soc. C 1969, 6, 923-928.

2. Abate, D.; Abraham, W.R.; Meyer, H. Cytochalasins and phytotoxins from the fungus Xylaria obovata. Phytochemistry 1997, 44, 1443-1448.

3. Chen, Z.M.; Huang, H.B.; Chen, Y.C.; Wang, Z.W.; Ma, J.Y.; Wang, B.; Zhang, W.M.; Zhang, C.S.; Ju, J.H. New cytochalasins from the marine-derived fungus Xylaria sp. SCSIO 156. Helv. Chim. Acta 2011, 94, 1671-1676.

4. Lin, Y.C.; Wu, X.Y.; Feng, S.A.; Jiang, G.C.; Luo, J.H.; Zhou, S.N.; Vrijmoed, L.L.P.; Jones, E.B.G.; Krohn, K.; Steingrover, K.; et al. Five unique compounds: Xyloketals from mangrove fungus Xylaria sp. from the South China Sea coast. J. Org. Chem. 2001, 66, 6252-6256.

5. Wu, X.Y.; Liu, X.H.; Jiang, G.C.; Lin, Y.C.; Chan, W.; Vrijmoed, L.L.P. Xyloketal G, a novel metabolite from the mangrove fungus Xylaria sp. 2508. Chem. Nat. Compd. 2005, 41, 27-29.

6. Wu, X.Y.; Liu, X.H.; Lin, Y.C.; Luo, J.H.; She, Z.G.; Li, H.J.; Chan, W.L.; Antus, S.; Kurtan, T.; Elsasser, B.; et al. Xyloketal F: A strong L-calcium channel blocker from the mangrove fungus Xylaria sp. (\# 2508) from the South China Sea coast. Eur. J. Med. Chem. 2005, 19, 4061-4064.

7. Liu, X.; Xu, F.; Zhang, Y.; Liu, L.; Huang, H.; Cai, X.; Lin, Y.; Chan, W. Xyloketal H from the mangrove endophytic fungus Xylaria sp. 2508. Russ. Chem. Bull. 2006, 55, 1091-1092.

8. Lin, Y.C.; Wu, X.Y.; Feng, S.; Jiang, G.G.; Zhou, S.N.; Vrijmoed, L.L.P.; Jones, E.B.G. A novel $N$-cinnamoylcyclopeptide containing an allenic ether from the fungus Xylaria sp. (strain \# 2508) from the South China Sea. Tetrahedron Lett. 2001, 42, 449-451.

9. Huang, H.R.; She, Z.G.; Lin, Y.C.; Vrijmoed, L.L.P.; Lin, W.H. Cyclic peptides from an endophytic fungus obtained from a mangrove leaf (Kandelia candel). J. Nat. Prod. 2007, 70, 1696-1699.

10. Wu, W.; Dai, H.; Bao, L.; Ren, B.; Lu, J.; Luo, Y.; Guo, L.; Zhang, L.; Liu, H. Isolation and structural elucidation of proline-containing cyclopentapeptides from an endolichenic Xylaria sp. J. Nat. Prod. 2011, 74, 1303-13088.

11. Boonphong, S.; Kittakoop, P.; Isaka, M.; Pittayakhajonwut, D.; Tanticharoen, M.; Thebtaranonth, Y. Multiplolides A and B, new antifungal 10-membered lactones from Xylaria multiplex. J. Nat. Prod. 2001, 64, 965-967.

12. Pittayakhajonwut, P.; Usuwan, A.; Intaraudom, C.; Veeranondha, S.; Srikitikulchai, P. Sesquiterpene Lactone 12,8-Eudesmanolides from the Fungus Xylaria ianthinovelutina. Planta Med. 2009, 75, 1431-1435.

13. Healy, P.C.; Hocking, A.; Tran-Dinh, N.; Pitt, J.I.; Shivas, R.G.; Mitchell, J.K.; Kotiw, M.; Davis, R.A. Xanthones from a microfungus of the genus Xylaria. Phytochemistry 2004, 65, 2373-2378.

14. Davis, R.A.; Pierens, G.K. ${ }^{1} \mathrm{H}$ and ${ }^{13} \mathrm{C}$ NMR assignments for two new xanthones from the endophytic fungus Xylaria sp. FRR 5657. Magn. Reson. Chem. 2006, 44, 966-968.

15. McDonald, L.A.; Barbieri, L.R.; Bernan, V.S.; Janso, J.; Lassota, P.; Carter, G.T. 07H239-A, a new cytotoxic eremophilane sesquiterpene from the marine-derived xylariaceous fungus LL-07H239. J. Nat. Prod. 2004, 67, 1565-1567. 
16. Silva, G.H.; de Oliveira, C.M.; Teles, H.L.; Pauletti, P.M.; Castro-Gamboa, I.; Silva, D.H.S.; Bolzani, V.S.; Young, M.C.M.; Costa-Neto, C.M.; Pfenning, L.H.; et al. Sesquiterpenes from Xylaria sp., an endophytic fungus associated with Piper aduncum (Piperaceae). Phytochem. Lett. 2010, 3, 164-167.

17. Wang, S.Y.; Xu, Z.L.; Mao, W.W.; She, Z.G.; Tan, N.; Li, C.R.; Lin, Y.C. Four new aromatic allenic ethers from the fungus Xylaria sp. No. 2508. Nat. Prod. Res. 2008, 22, 612-617.

18. Xu, F.; Zhang, Y.; Wang, J.J.; Pang, J.Y.; Huang, C.H.; Wu, X.Y.; She, Z.G.; Vrijmoed, L.L.P.; Jones, E.B.G.; Lin, Y.H. Benzofuran derivatives from the mangrove endophytic fungus Xylaria sp. (\# 2508). J. Nat. Prod. 2008, 71, 1251-1253.

19. Song, Y.; Wang, J.; Li, S.; Cheng, B.; Li, L.; Chen, B.; Liu, L.; Lin, Y.; Gu, Y.-C. Metabolites of mangrove fungus Xylaria sp. BL321 from the South China Sea. Planta Med. 2012, 78, 172-176.

20. Song, Y.X.; Cheng, B.; Zhu, X.; Qiao, L.T.; Wang, J.J.; Gu, Y.C.; Li, M.F.; Liu, L.; Lin, Y.C. Synthesis and cytotoxic evaluation of eremophilane sesquiterpene 07H239-A derivatives. Chem. Pharm. Bull. 2011, 59, 1186-1189.

21. Shiono, Y.; Murayama, T. New eremophilane-type sesquiterpenoids, eremoxylarins A and B from xylariaceous endophytic fungus YUA-026. Z. Naturforsch. B 2005, 60, 885-890.

22. Puar, M.S.; Barrabee, E.; Hallade, M.; Patel, M. Sch 420789: A novel fungal metabolite with phospholipase D inhibitory activity. J. Antibiot. 2000, 53, 837-838.

23. Du, Z.Y.; Liu, R.R.; Shao, W.Y.; Mao, X.P.; Ma, L.; Gu, L.Q.; Huang, Z.S.; Chan, A.S.C. alpha-glucosidase inhibition of natural curcuminoids and curcumin analogs. Eur. J. Med. Chem. 2006, 41, 213-218.

24. Lee, S.S.; Lin, H.C.; Chen, C.K. Acylated flavonol monorhamnosides, alpha-glucosidase inhibitors, from Machilus philippinensis. Phytochemistry 2008, 69, 2347-2353.

(C) 2012 by the authors; licensee MDPI, Basel, Switzerland. This article is an open access article distributed under the terms and conditions of the Creative Commons Attribution license (http://creativecommons.org/licenses/by/3.0/). 